\title{
Confronting Otherness through Theatre: On Directing The Merchant of Venice for Thai Audiences
}

\author{
Dangkamon Na-pombejra (ดังกมล ณ ป้อมเพชร) \\ Assistant Professor, Department of Dramatic Arts, Chulalongkorn University, \\ Bangkok, Thailand \\ heisacat@yahoo.com
}

\begin{abstract}
This article analyzes on a new directorial approach to Venice Vanija (เวนิสวาณิช), a Thai version of William Shakespeare's The Merchant of Venice (written 1596-99) and translated by King Rama VI (r. 1910-1925). It aimed to create a new space and new rules that would encourage Thai audiences to embrace new perspectives by watching the performance. The production was directed by the author in 2018 in the Department of Dramatic Arts in the Faculty of Arts at Chulalongkorn University.

The directing approach focused on the play's famous line "all that glitters is not gold;" (Act II, scene vii, line 65), and stressed how struggles between majorities and "the Other" are connected to identity conflicts that contrast with tensions with other people and conflicts within the whole community.

The above focus was elaborated by using alienation effects, including a grotesque modern fairytale-like look, a nearly all-female cast, a distinctive traverse stage and set design, effeminate costumes for male characters portrayed by actresses, and mixed acting techniques.

The director achieved his goals by concentrating on the message and the main conflicts in the play, transforming "aliens into the allies" through using good surprises and friendly attacks, and respecting every party.
\end{abstract}

\section{Keywords}

theatre directing - Thai theatre - Shakespearean play - audience perception - The Merchant of Venice 
บทคัดย่อ

เผชิญหน้าความเป็นอื่นผ่านละครเวที : การกำกับการแสดงละครเรื่อง เวนิสวาณิช สำหรับ ผู้ชมชาวไทย

บทความนี้วิเคราะห์แนวทางใหม่ในการกำกับการแสดงละครเวทีเรื่อง เวนิสวาณิช (ปี พ.ศ. 24532468) บทพระราชนิพนธ์แปลในพระบาทสมเด็จพระมงกุฎเกล้าเจ้าอยู่หัว จาก The Merchant of Venice (ปี พ.ศ. 2139-2142) ของวิลเลียม เชคสเปียร์ โดยผู้กำกับการแสดงต้องการสร้างพื้นที่ และกติกาใหม่ให้ผู้ชมละครเปีดรับมุมมองใหม่ขณะที่กำลังชมการแสดง ละครเวทีเรื่องนี้เป็นละคร ประจำปีการศึกษา 2560 ของภาควิชาศิลปการละคร คณะอักษรศาสตร์ จุพาลงกรณ์มหาวิทยาลัย กำกับการแสดงโดยผู้เขียนบทความ

แนวทางในการกำกับการแสดงละครเรื่องนี้มุ่งโฟกัสที่วรรคทองของบทละครที่ว่า “วาว ๆ บ่ใช่ เนื้อ คำดี ทัวนา" (องก์ที่ 2 ฉากที่ 7 บรรทัดที่ 65 ) และเน้นให้เห็นว่าการต่อสู้ระหว่างคนหมู่มากของ สังคมกับผู้ที “เป็นอื่น" นั้น สัมพันธ์กับวิกฤตอัตลักษณ์ของตัวละครซึ่งมักตรงกันข้ามกับบุคคลอื่น และความขัดแย้งในสังคมโดยรวม

การข้างต้น ขับเน้นและขยายให้ชัดเจนด้วยการใช้กลวิธีในการทำให้ถอยห่าง อันได้แก่ วิลักษณ์ ของรูปแบบที่คล้ายกับเทพนิยายสมัยใหม่ คณะนักแสดงที่เป็นหญิงเกือบทั้งหมด เวทีและฉากแบบ ผ่ากลางที่นั่งผู้ชม เครื่องแต่งกายที่เน้นความเป็นหญิงของตัวละครชายที่แสดงโดยนักแสดงหญิง และเทคนิคการแสดงแบบผสมผสาน

วัตถุประสงค์ของผู้กำกับการแสดงสัมฤทธิ์ผลได้ด้วยการยึดความคิดหลักและความขัดแย้งหลัก ของละครเป็นแกนในการนำเสนอ การเปลี่ยน 'ความเป็นอื่นให้เป็นพันธมิตร' โดยการสร้างความ ประหลาดใจเชิงบวกและการกระตุกผู้ชมอย่างเป็นมิตร ตลอดจนการให้เกียรติและเคารพทุกฝ่าย

\section{Introduction: Confronting Otherness ${ }^{1}$}

This article focuses on using theater to help contemporary Thai audiences to better accept "otherness" and to tolerate differences which oppose their expectations, familiarity and preferences. The development of this approach to using theatre emerged through the process of directing a production of Venice Vanija (เวนิสวาณิช), a Thai version of The Merchant of Venice. Developed as a production in the Department of Dramatic Arts at Chulalongkorn University during 2017, this production was staged in early February 2018 in the Sodsai Pantoomkomol Centre for Dramatic Arts of Chulalongkorn University's Faculty of Arts, Bangkok, Thailand. ${ }^{2}$

1 See the photos of this article at the URL https://doi.org/10.6084/mg.figshare.13247129.

2 This production was done as part of a three-year national umbrella project funded by the former Thailand Research Fund project (2016-2019) called "Performance Research: Doing Creative Research in Contemporary Thai Performing Arts" (RTA 5980010) run by Professor Pornrat Damrhung out of Chulalongkorn University in Bangkok. In 2019 the Thailand Research Fund was folded into the new Thailand Science Research and Innovation (TSRI). 
The question posed by the author of this article, who directed this production was this: how can the director convey the key message of The Merchant of Venice play to contemporary Thai audiences - who often carry stereotypical views of the play due to their inadequate exposure to it in school - and thereby help them to better accept those who are different from themselves? Many Thais have limited perceptions which are affected by their memories, understanding, expectations and beliefs of what the play is about. There is a standard preconceived view of The Merchant of Venice for many ordinary Thai people as a pure romantic comedy, in which Portia "the cleverest and fairest heroine" beats Shylock, the miserly and notorious Jew, who is "the inhuman villain," and thus is able to save life of Antonio, the angelic merchant of Venice, who is mutual and beneficent friend of Bassanio (Portia's handsome-andhumble knightly husband). This view of the play stresses a kind of poetic justice, seeing Christians as kind and virtuous while the Jew is someone immoral; so the good naturally conquers evil. This deeply engrained view held by many Thai people comes from their narrow exposure to the notion of difference tied to this play from their school education. It ignores the fact that The Merchant of Venice is equally a problem play which deals with controversial social issues through dialogues between characters who represent conflicting points of view, often in a realistic social context. ${ }^{3}$

This production of Venice Vanija (เวนิสวาณิช) based on The Merchant of Venice thus aimed to change minds. Specifically, it sought to communicate issues and perceptions that differ from and are at odds with the instilled views of the play for its audiences, not only to provide a new vision of the play, but also to provide new views of people, their communities, the world and their own selves. Toward this end, the production used the ideas of "cognitive bias" and "cognitive dissonance" found in LaConte Consulting (2020), which state that "the cognitive bias is a systematic pattern of deviation from rational judgment that often leads to a distorted perception, illogical interpretation, and/or inaccurate conclusions, while the cognitive dissonance is a mental stress that

The author would like to thank the two anonymous reviews for providing thoughtful comments on an earlier version of it. I have used their comments and suggestions to revise, elaborate and clarify some parts of the paper, making it a better paper as a result.

3 A "problem play" is a "type of drama that developed in the 19th century to deal with controversial social issues in a realistic manner, to expose social ills, and to stimulate thought and discussion on the part of the audience." (Encyclopedia Britannica online 1998). It is most strongly tied to the works of Henrik Ibsen but also includes George Bernard Shaw and others. Starting from the late 1800 s, Shakespeare critics also used the term "problem play" to refer to several Shakespeare plays dealing with a contemporary social problem through the subject matter of the play, the classification 'problem' with the plays themselves. Problem plays from Shakespeare's works often include All's Well That Ends Well, Measure for Measure, and Troilus and Cressida, plus The Winter's Tale, Timon of Athens, and The Merchant of Venice. 
occurs when an individual is confronted with information that is inconsistent with or contradicts their beliefs, ideas, and values." The production thus sought to rework the play in a way that would provide the audience with an encounter with otherness so they could confront their own cognitive dissonance and cognitive bias, and possibly make them more tolerant and accepting of difference.

The Merchant of Venice has been well-known in Thailand for more than a century. In 1913, Rama VI (r. 1910-1925) provided Thai readers with a version of Shakespeare's The Merchant of Venice using a type of interpretive translation called "tradaptation." His "tradapted" version of the play, according to his preface, sought to show that the civilization of the Thai people and Thai language is equal to that of the West.

To highlight this goal, in 1923, the Ministry of Education of Thailand added King Rama vi's tradapted version of The Merchant of Venice to the required reading list in "Thai literature" classes for high school students. The Ministry went on to make it required reading for junior high school students in 1960. Despite its familiarity to Thai students, it is unfortunate that they are normally asked to read only some scenes and some quotations of Rama VI's tradaptation, according to Thongthong Chandrangsu (2018). Moreover, Suwandee Chakravoravudh (2018) recounts that when she read these parts as a junior high school student, she regarded all characters in the play as mere stereotypes.

It can be said that the Thai education system treated Venice Vanija as a part of Thai literary anthology. Therefore, when Thai schools study this play, they focus on literary aesthetics more than on sociological analysis. (Patama Chancharoensuk 2011, 14-15)

The reading guide at the end of the 1940 official printing (Ministry of Education 1940, 309-319) mainly focuses on poetic analysis, vocabulary definition, a broad analysis of main characters and language questions, neither analyzing the characters' psychology as human being, nor comparing the situation in the play with the contemporary social context of students.

Moreover, categorizing the book as a joyful play or "Lakorn rerng romya" as it was labeled on the cover of its original printing, it is clear that it was seen as a romance of young lovers who can overcome the malice of a cruel villain.

Nopamat Veohong (2018) provides more details on this, stating that Thai people became accustomed to this "tradapatation" because it was also used as 
a textbook for "modern" Thai poetry. Most students who have studied for any length of time in the Thai school system are not only able to recite famous quotations from this version of play, but they can also write out three famous classic lines from memory, dealing respectively with the mercy of mankind, with fanciful love and with the meaning of music. Because of this situation, few people in Thailand have ever read the entire play or seen it staged, whether in English or in Thai.

Judsri Maneedeng (2018) notes that even though general audiences like her do not know much about the play, she expected the play to be a romantic comedy with humor in it.

These deeply held general Thai perceptions of the play persist despite the fact that Shylock's monologue in Act III, scene i, expresses his deep grievance with his treatment:

Hath not a Jew eyes? Hath not a Jew hands, organs, dimensions, senses, affections, passions? Fed with the same food, hurt with the same weapons, subject to the same diseases, healed by the same means, warmed and cooled by the same winter and summer as a Christian is? If you prick us, do we not bleed? If you tickle us, do we not laugh? If you poison us, do we not die? And if you wrong us, shall we not revenge? If we are like you in the rest, we will resemble you in that. If a Jew wrong a Christian, what is his humility? Revenge. If a Christian wrong a Jew, what should his sufferance be by Christian example? Why, revenge. The villainy you teach me I will execute—and it shall go hard but I will better the instruction.

This heartfelt and heart-rending monologue from the play is virtually unknown by most ordinary Thai people. The play was staged, in part, to help this neglected side of the play become better known, and with it the stronger call for recognizing human dignity embedded within it.

\section{Audiences' Sensual Engagement and the Alienation Effect}

How to do this? Stephen Di Benedetto (2011) provides one approach in his chapter "Sensual Engagements: Understanding Theories of the Senses and their Potential Applications within Theatre Practice" which suggests that "three basic concepts... can help us understand how we process and interpret stimuli generated by an artistic event are perception, consciousness and attention. Our perception of reality and fiction is influenced from both consciousness and unconsciousness mechanisms dependent on our knowledge, experience, 
memory and expectation. ...Controlling the context of performance is then a biological process of conveying meaning." (Di Benedetto 2011, 102)

Bernard J. Baars (1997) likewise suggests that a spotlight of attentiveness rises when our mind's attention is drawn to a particular stimulus, due to our neural processes unconsciously producing the instant experience of what now communicates with us, just before our consciousness becomes infected with social learning and habitual experiences of interacting with the world around us. He uses Endel Tulving's work (Tulving, et al., 1994; Tulving and Kroll 1995) to remind us that a key function of brain activity is "mismatch-detection: spotting events that violate our expectations and triggering attentional mechanisms to direct the surprising events to consciousness. When we encounter unexpected stimuli, we are forced to pay attention to this disjunction which can help guide our interpretation." (Baars 1997, 107)

Di Benedetto (2011) concludes, stating that "as practitioners begin to make use of production techniques that challenge spectators' expectation of what performance should be like and how it is meant to be understood, they face the challenge of how to lead attendants to reassess their means of perception." (Di Benedetto 2011, 113)

As the director of the new The Merchant of Venice production, I sought to turn the above concepts and observations into the distancing devices or the alienation effects used by Bertolt Brecht in his theory of drama.

The "alienation effect" or "distancing effect" is a key concept from Brecht's drama theory, consisting of:

the use of techniques designed to distance the audience from emotional involvement in the play through jolting reminders of the artificiality of the theatrical performance.... [These] techniques include explanatory captions or illustrations projected on a screen; actors stepping out of character to lecture, summarize, or sing songs; and stage designs that do not represent any locality but that, by exposing the lights and ropes, keep the spectators aware of being in a theatre. The audience's degree of identification with characters and events is presumably thus controlled, and it can more clearly perceive the 'real' world reflected in the drama.....By creating stage effects that were strange or unusual, Brecht intended to assign the audience an active role in the production by forcing them to ask questions about the artificial environment and how each individual element related to real-life events. In doing so, it was hoped that viewers would distance themselves emotionally from problems that demanded intellectual solutions. (Encyclopedia Britannica online 2020) 
Some common alienation effects or distancing devices include:

1. The use of theatricalism or non-realistic devices to emphasize to viewers to be aware all the time while watching the performance that they are watching a constructed illusion, not reality, so they should use their critical minds rather than their emotions to assess the character's behavior or the situation on stage. Specific types of devices include non-realistic acting, singing and dancing, a bare stage and mime.

2. The use of grotesqueness, including incompatibilities, novelties and exotic elements, such as a far distant kingdom setting and cross-gender casting.

3. The disruption of emotion and sequences such as narrating ab event in advance of its occurring, the grotesque element, or an unbelievably surprising turning point, al used remove their audiences from the illusion of the drama and to put their minds to work to question or argue with the character(s).

These concepts and tools were also key devices the director used to create a new version The Merchant of Venice.

The key message of The Merchant of Venice, is found in the famous line:

all that glitters is not gold; (Act II, scene vii, line 65).

Other major themes of the play include:

The quality of mercy is not strain'd, (Act IV, scene i, line 173).

and

"Nothing is good, I see, without respect: Methinks it sounds much sweeter than by day." (Act $\mathrm{V}$, scene i, lines 107-108).

Interestingly, "mercy" is defined as both "compassion or forbearance shown especially to an offender or to one subject to one's power," and also a blessing that is an act of divine favor or compassion." (Merriam-Webster) What is more, to be "at someone's mercy" indicates a person is "without defense against someone." (McGraw-Hill).

The main conflicts of the play work through dichotomies and binary opposites, where biases of the majority against "the other" or those who are different work in the interpersonal conflict of identity versus conflicts against other people and conflicts against the whole community.

Given the goals of the production, the main conflicts of the play are between: 


\begin{tabular}{|r|c|c|}
\hline The Majority \& The Mainstream & VS & $\begin{array}{r}\text { The Minority, The Marginalized, } \\
\text { The Others, The Queer }\end{array}$ \\
\hline $\begin{array}{r}\text { The Catholic, white people of Venice } \\
\text { and Belmont }\end{array}$ & VS & $\begin{array}{r}\text { The Jews, The Moor, } \\
\text { The Convert }\end{array}$ \\
\hline $\begin{array}{r}\text { Who and what the character } \\
\text { idealistically wants to be and to gain }\end{array}$ & VS & $\begin{array}{l}\text { Who and what he/she/it realistically } \\
\text { turns out to be and to accept }\end{array}$ \\
\hline
\end{tabular}

FIGURE 1 Director's view of the main conflicts in the The Merchant of Venice play.

E and F represent the inner conflict of the main characters of the play.

To realize the above goals as director, I sought to make the script and the production concise, lean and clean, focusing on the main action and main conflicts, schematized below:

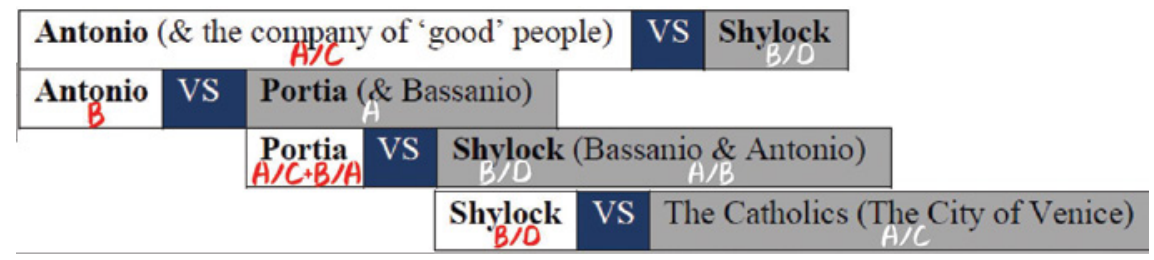

FIGURE 2 Main action and main conflicts focused on in the Director's version of The Merchant of Venice

This was done through several steps.

First, I cut and trimmed long lines, omitted scenes of minor plots, biblical allegories, some allusions and mythological references, such as the story of Jacob from Genesis 30 and the scene of punning game between Lorenzo, Jessica and Lancelot in Act III, scene v, since these items would be difficult for Thai audiences to understand.

Second, I combined some minor characters together, including the roles of servants and the role of Salerio in Act III, scene ii.

Next, I rearranged some scenes to smooth the logic and the flow of the play and to make the through-line of action and emotion of characters clearer and seamless. So in Act III, scene ii, the director had Bassanio read the letter from Antonio first, then had Portia and Jessica offer their help.

Fourth, I sought to retain the poetic quality and the spirit of Shakespearean language in Thai, especially in famous quotes from the play, such as "Tell me 
where is fancy bred..." (Act III, scene ii) and also the poems tied to the choosing of the three caskets in Belmont.

Fifth, I limited the length of the performance to no longer than three hours, with a 15-minute intermission, to ensure maximal audience attention, concentration and to better fulfill the larger goals of the production.

Finally, I reworked the new version of the adapted script as a prose play rather than in poetry, both to aid the actors in the delivery of their lines as naturally spoken words, and to better help audiences comprehend what is going on.

The message and the main conflict of the play are emphasized and elaborated, not just through the reworked script, but also by using "alienation" or "distancing" effects. The techniques to do this included the following:

First, by presenting the production in a grotesque style of a modern fairytale. The set design, music and songs, costumes and the heightened language were all arranged to achieve this goal.

The director chose to retain the original tone of the play, seeing it as a fairy tale set in real life, which was both dark and lively. This formed the major tone of the production. The production also interwove contemporary and historical elements, sometimes in harmony and sometimes in tension with one another. They reflected the conflict between an "idealistic imaginary" or "cognitive memories" and "what is actually happening to contradict the ideal, the expected or cognitive memories." These tensions were as true for the characters as they were for the audiences. In addition, the spectacle and sounds on the stage help to reflect the attitude and behavior of the characters who were yearning to present their idealistic images to the public, like to their contemporaries.

The director had Portia recite this song, along with the dance of her maids, thus giving hints and signals to Bassanio to pick the right casket. The background music was by the "Postmodern Jukebox," a rearrangement of a popular song in a classical jazz style.

Secondly, since the production used a largely female cast, the mostly female actors portrayed the white Christian male characters, who were the majority in the community of in Venice at that time, while the two male actors played the Jew and the Moor, who represented the marginalized and minority groups in the play. The use of multi-role casting also reflects the fluidity of role-playing, and the role and status transformation of male and female characters in the play and in our real life today. 
The male actor who played Shylock was just one of the two male actors in this production, while there were nineteen female actors in the cast. In the scene at the court of justice, the actor Shylock was the only male figure on the stage, surrounded and cornered by female actors.

Thirdly, the physical set of the play used a traverse, bare stage, with sets for buildings on each end. This canal-like stage provided the main acting area, and further represented the central market of the Rialto Bridge, the city street, etc., while the audience watched from both sides, observing the disputes between the characters as if they were at a sporting tournament. The buildings set on each end of the stage represented Shylock's house in the Jewish Ghetto, a gentlemen pub, a jailhouse and Portia's luxurious mansion in Belmont.

The major scene of the play occurs in Act IV, scene i, and uses the full setting of the production to better depict the full scope of Shylock's judgement day, which occurs in the square of Saint Mark's cathedral in front of the Doge's palace in Venice. This set also plays a figurative role, symbolizing action taking place at the intersection of the Christian and the Venetian political power field (represented by the cathedral and the Doge), where Shylock the alien is cornered and locked down in the space surrounded by sculptures and buildings representing the Christian and Venetian system of laws and punishments, and then crushed by Venice's Christian "mercy."

In addition to the set, the costumes were designed to show an effeminacy for those worn by the Christian male characters played by women. The performances as males by these actresses also reflects concepts the director wanted to include in the production: namely those of the transformability, performativity, and différance of their role-playing and their gender roles. ${ }^{4}$

Fifthly, the use of stylized acting techniques such as a larger-than-life acting style, heightened language, semi-dance movements, among other techniques are blended with more realistic acting approaches to stress the theatrical construction of the issues addresses in the production, again used to play up on the alienation effects.

Finally, the historical background of the mistreatment of Jews in Italy, the use of blood libel, the meaning of the places in the Judgement Scene (Act IV,

4 "Transformability" refers to the use of some sign or form in a different way from cultural convention, especially in theatrical performance. "Performativity" is a concept Judith Butler develops to show how gender identity emerges as "a performative accomplishment... compelled by social sanction and taboo.... Gender is... an identity instituted through a repetition of acts" which is seen in the acting done in this production, too. The concept différance is used by Jacques Derrida to refer to both the "difference and deferral of meaning," stressing that significance and meaning is created rather than given, just like in this production. 
scene i) and the information about the problem play are also provided in more detail to the audience in the show program notes to further highlight their significance to the production.

\section{Public Responses to the Production}

Venice Vanija was the Thai name for this 2018 version of The Merchant of Venice. It was staged twelve times by the Department of Dramatic Arts of the Faculty of Arts in Chulalongkorn University in February 7-18, 2018 at the university's Sodsai Pantoomkomol Centre for Dramatic Arts. Audience responses were collected from survey questionnaires, two post show talks, personal interviews and public reviews. In what follows I will consider the responses to a questionnaires filled out by audiences who attended the production and some published reviews of the production to help assess different ways the production affected audiences. For the full results and details on the audience responses to the questionnaires for this play, see the Thai Performance Practice as Research Facebook page run by the Department of Dramatic Arts of Chulalongkorn University. <https://www.facebook.com/ThaiPerformancePracticeResearch> (Na-pombejra 2018)

\subsection{Surveys Conducted of Audiences after the Production}

The total number of the audience who attended the production was 1,408, divided into 589 students, 41 retired persons, 222 general audiences, 244 students of the Faculty of Arts at Chulalongkorn University, and 312 invited guests, reviewers and press. For details on the audience responses to the questionnaires, see Dangkamon Na-pombejra (2018). What follows are the main findings of these questionnaires.

The audience response data seen in the appendix produced the following interesting results in light of the author's research question. First, more than two-thirds of the 956 respondents who attended the production were female university students aged $15^{-29}$ years old. Less than half of the audiences at the production had read or were very familiar with Shakespeare, having never read all of a Shakespeare play - in whatever language - or seen a Shakespeare production. Of those who attended the production with some familiarity with Shakespeare, Macbeth, Romeo and Juliet, along with The Merchant of Venice, A Midsummer Night's Dream, Hamlet, and Twelfth Night were among the most familiar of his plays.

As for audience responses to the production itself, more than half took "prejudice and discrimination against 'the other" as the main message or 
theme, followed by "justice and injustice of the majority." Pluralities of the audiences saw the main conflict in the play as rooted in "Our Folks vs Their Folks," then "The Majority vs The Minority/The Marginalized/"The Other," followed by "Love vs. Hatred." Much of the audience likewise saw the adapted script as retaining "the beauty of the original play" as well as concisely presenting the plot and effectively focusing on the main message of the play. Many audience members saw the actors as both clearly articulating their lines and expressing the beauty of the language, and they saw the actors as doing well to convey the play's message through their acting and the sound and spectacle of the performance, followed by having "female actors portray the majorities and male actors play the marginalized." In particular, the character Shylock helped audiences "understand the message of the play", followed by Portia and Antonio, all three of whom were seen to be "believable, logical and empathetic" in roughly the same proportion. Watching the production helped the audience to change several aspects, such as their view of "people, life, and realities," themselves, others, and their communities, as well as The Merchant of Venice and Shakespeare's plays.

\subsection{Selected Published Reviews to the Production}

For another perspective on the responses, the author will consider two reviewers' perspectives on the production.

Excerpt from "The Merchant of Venice ... Or is there such mercy?"

This review is by Danuphat Lohaphongsathorn (2018), who is a wellknown professional critic and content creator writing for several trendy Thai metropolitan online magazines dealing with contemporary culture, style and politics such as A Day Bulletin, The Momentum, The Cloud, GQ Thailand, etc. In A Day Bulletin on February 15, 2018, he wrote of the play:

When did you first know Venice Vanija or the Thai version of The Merchant of Venice? For me, it was first known as a part-time reading requirement when I was a grade 10 student. Comparing to the first time, I found watching the production of the play this evening gave me the totally different feeling as if I had never known the play before. I believe it is because of my present worldview that makes me recognize Venice Vanija in a completely different perspective.

Every theatrical element of this production; the script, the actors, acting, scenery, lighting, music, costume, even the audiences' emotions which were infused within the theatre, helped me to be sunk in and have an inking about things that might be hidden deeply within the human 
heart. I, thus, realized that what I knew and understood when I was a student is just a tip of iceberg floating above water. The picture I see may not be an exact truth that can be trusted completely.

Is the love of Bassanio' and Portia, in fact, due to the hope of profit?

Is Antonio's love for Bassanio, actually, more than friendship?

Does Shylock's vindictiveness need to be more considered deeply than the surface?

Or is there no such mercy?....

The vibe of history of Jews and Christians in Venice was set as the backdrop of the performance of Venice Vanija. Throughout the show, it urged me to come up with the above questions and slowly lighted me up until the answer to the value of humanity was crystal clear, especially the issue of Shylock's malice.

Politics, power, the restriction of rights and the conviction in old Venice were the important mechanisms for the freedom of the Christians and the constraint of the Jews. These also divided Venetian people into two groups.... All these had been picked up and inserted into the detailed creation of the production, ingeniously and perfectly, especially toward the script adaptation, the acting and the actors, as intended by the director and the script adaptor.

As the play ended, in the midst of the applause from the audience, I felt that I didn't hate Shylock for his resentment anymore. I understand now why he was so zealous to slit his enemy's flesh. Still, I still insist that I disagree with his desire to kill Antonio.

Excerpt from "Venice Vanija: The Comedy of Reconsideration." On the Connecting Dots Wordpress site, Judsri Maneedeng (2018), the pen name of a noted independent online critic who reviews current urban Thai culture and entertainment, posted the following on February 17, 2018:

... I walked into the theater hoping to enjoy myself watching a comedy, which I did laugh all through the performance. Anyway, when it came to the judgement scene which the team of Bassanio and Antonio won the case, I as an audience felt so ill at ease. I could not be pleased with the "good guys" as I should. The ganging up of the Christian characters in the trial made me feel the injustice was there. The gratified laughter of Bassanio's gang when they won, repulsed me. Shylock, the villain in the play, on the other hand received my sympathy, even though I did not agree with his cruelty. 
I then thought that I felt uncomfortable, even though the play was only a comedy, because I grew up in the age that racism and minority oppression were unacceptable. But after I had done the post-show questionnaire, I was finally aware of the fact that this feeling was actually the intention of the production. Besides, I thus understood why I felt that way after I had read the program of the show later.

Shylock's monologue in the play let us hear what he felt to be the abused all through his life. Being a Jew, Shylock cried he also had a heart, felt hot and cold and got hurt, similar to the Christians. For me, these lines were part of the empathy and sympathy arousal toward Shylock.

The heart of the play might not be only the begging for mercy from Shylock to spare Antonio's life.

Actually, it is the call for mercy on fellow human beings and the respect for all the differences, regardless of race, religion, or class.

I finally realized that the show was not only a play for laughs, but a play for re-consideration. I was absolutely amazed at the creator of the production that he could contribute such idea to the one who knew nothing about this issue like me. The director and the script adapter of the production applied techniques and details to communicate his message more clearly, such as the use of female actors playing Christian characters and male actors portraying Jews and Muslim, picturing the majorityminority society.

These different audience responses suggest the production was able to achieve its desired effect of "changing minds" by communicating issues and perceptions at odds with the standard views of the play for audiences through the new vision of the play and new views of the people, their communities, the world and themselves.

\section{5 \\ Discussion}

The author will now discuss some of the implications of this production from three different perspectives: the interpretation and script adaptation, the role of the audience, and the mode of presentation.

Since the production of The Merchant of Venice focused exclusively on representing the key message embedded in the line "all that glitters is not gold;" (Act II, scene vii, line 65), the main conflicts and main action of the play, it was 
easier to provide a unified view of the whole drama and to make the message concrete, concise, and poignant. The open-endedness of the production from this perspective is something as true for the character(s) in the play as it is for the audiences of the production. For both, the production asks what they would do when they confront "the other." Since the production was designed as a problem play, it was able to urge its audience to reread, revise and reconsider the problems shown in the play in light of their own experience and their own lives. The adaptation of this production still maintains its poetic quality, which helped to satisfy audience expectations.

Although some respondents still retained their views on gender roles after viewing the production, they showed they were more willing to reconsider and revise their views on how they evaluate people and things, if they could be provided enough connection to characters and comprehensive information. Some noted they could even accept their misunderstanding and cognitive bias. Audiences responded to the social issues in the production like injustice of the majority against marginalized groups more strongly than the philosophical issue like the meaning and value of life.

The use of the fairy-tale like setting and a grotesque mode of presentation helps the audience to recognize the différance and performativity of the ideal, perception, memory, belief, the subjective cognition and reality. The use of female actors to portray the majority or dominant roles and male actors playing the marginalized roles was able to effectively communicate with some audience members. These techniques also helped to highlight the platonic and fraternal friendship between Antonio and Bassanio as the original play represented. The effeminacy of the costumes of the male characters performed by female actors helps to reflect the performative aspect of gender in social life.

\section{6}

\section{Conclusion}

As the director of the production The Merchant of Venice in Bangkok, the author discovered three key practices to help achieve the desired objectives of this work indicated earlier in the article.

First, by concentrating on the message and the main conflict of the play, the production became a more concise, incisive, and lively three-hour play.

Secondly, by using "good surprises," including efforts to not attack the audiences' confidence and ego, but to provide a surprise that the audience feels good and is fun to be surprised with, the production was able to give them a 
new perspective. By contrast, the use of "friendly attacks" made things seem to be a type of novelty that is not strange, something friendly and more acceptable to viewers, without pushing them back with negative feelings, so they are able to transform those who at first seem to be aliens into allies of the audience. This helps engage the audience with what they are familiar with before they are introduced to something new to and different from to their expectation and views. These tactics allowed the audiences to better appreciate the contrast between them.

Finally, by respecting every dimension of the play's ecosystem - the audience, the actors, the original Shakespeare play, King Rama vi's adaptation of it, the contemporary context and all differences among them, the play gains more depth and significance.

In confronting otherness, both the characters in the play and all of us in the theatre, whether making or viewing the play and in our real lives, tend to treat "the other" as a threat and to devalue this other as a defense mechanism which helps to protect our sense of identity. To learn to cope with or even to embrace otherness involves an active practice involving our mindset and perception. If we are all capable of engaging a new mode of perceiving different things and people with fewer forms of cognitive bias, we will be able to gain a larger sense of mercy and humility in ourselves and our interactions would be more open and inclusive.

\section{References}

Baars, Bernard J. 1997. In the Theatre of Consciousness: The Workspace of the Mind. Oxford: Oxford University Press.

Chakravoravudh, Suwandee. 2018. "Post Show Talk, show\#4." February 10, 2018. (in Thai).

Chancharoensuk, Patama. 2011. "Politics and the Political in Venice Vanich by H. M. King Rama VI." PhD diss., Thammasat University (in Thai).

Chandrangsu, Thongthong. 2018. "Venice Vanija, Lakorn Aksorn Chula 2018." Facebook, February 8, 2018. http://www.facebook.com/nha.chandransu?hc_ref=ARS khaiRFFmlbgiw5Oaeyhg_aqlR3omCZTcI48A HhkF-sLovioV9denNXAxı6oWGLww (in Thai).

Di Benedetto, Stephen. 2011. "Sensual Engagements: Understanding Theories of the Senses and their Potential Applications within Theatre Practice." In Playing with Theory in Theatre Practice, edited by Megan Alrutz, Julia Listengarten, and M. Van Duyn Wood, 102-13. New York: Palgrave Macmillan. 
The Editors of Encyclopedia Britannica. 2020. "Alienation Effect." In Encyclopedia Britannica online. https://www.britannica.com/art/alienation-effect. Accessed May 15, 2020.

The Editors of Encyclopedia Britannica. 1998. "Problem Play." In Encyclopedia Britannica online. https://www.britannica.com/art/problem-play Accessed May 15, 2020.

LaConte Consulting. 2020. "Strategic Risk Definitions: 'Cognitive Bias' and 'Cognitive Dissonance.” https://laconteconsulting.com/definitions/. Accessed May 15, 2020.

Lohaphongsathorn, Tanuphat. 2018. "The Merchant of Venice ... Or is there such mercy?" A Day Bulletin, February 15, 2018. https://adaybulletin.com/the-review-merchant -of-venice-artscu61/14532 (in Thai).

Maneedeng, Judsri. 2018. “Venice Vanija: The Comedy of Reconsideration." In Connecting Dots by Judsri, February 17, 2018. https://judsri.wordpress.com/2018/02/17/ (in Thai).

McGraw-Hill Dictionary. 2020. "At the mercy of" http://idioms.thefreedictionary.com/ at+the+mercy+of. Accessed May 15, 2020.

Merriam-Webster Dictionary. 2020. "Mercy" https://www.merriam-webster.com/dic tionary/mercy. Accessed May 15, 2020.

Ministry of Education. 1940. "Study Guide." In Venice Vanija, a Poetry Textbook, 309319. PDF. http://164.115.27.97/digital/items/show/10224 (in Thai).

Na-pombejra, Dangkamon. 2018. "Survey Results of Audiences Attending Venice Vanija, February 7-18, 2018 at the Sodsai Pantoomkomol Centre for Dramatic Arts." https:// www.facebook.com/ThaiPerformancePracticeResearch Accessed September 7, 2020.

Shakespeare, William. 2015. The Merchant of Venice. Cambridge: Cambridge University Press.

Tulving, Endel, Shitij Kapur, Fergus I. M. Craik, and Morris Moscovitch. 1994. "Hemispheric Encoding/retrieval Asymmetry in Episodic Memory: Positron Emission Tomography Findings." Proceedings of the National Academies of Science 91 (6): 2016-20.

Tulving, Endel, and Neal Kroll. 1995. "Novelty Assessment in the Brain and Long-term Memory Encoding." Psychonomic Bulletin and Review 2 (3):387-90.

Vajiravudh, King. 200o. Venice Vanija, a Poetry Textbook, 48th ed. Bangkok: Ministry of Education (in Thai).

Veohong, Nopamat. 2018. "Post Show Talk, show\#10." February 17, 2018. (in Thai). 